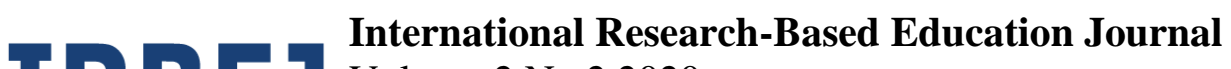 \\ Volume 2 No 22020 \\ Available online at IRBEJ website: \\ http://journal2.um.ac.id/index.php/irbej
}

\section{Prevention of Covid-19 Spread in Kunti Village Bungkal Ponorogo Village Through the Use of Steriles Booths}

\author{
Anggiya Dwi Nanda* \\ Princess Julianti \\ Universitas Negeri Malang \\ (corresponding author) $^{*}$ \\ $\checkmark$ anggiyadwi@gmail.com
}

\begin{abstract}
The Covid-19 virus pandemic hit the whole world in early 2020. This new virus was first discovered in Wuhan, Hubei Provision, China. Many countries affected by this virus, including Indonesia. The percentage of deaths caused by this virus reaches $9.11 \%$. Vaccines for this virus have not yet been found.This inspired the Covid edition of students social works at Universitas Negeri Malang to make a breakthrough in preventing Covid-19 transmission. One of the work programs that shows a breakthrough in preventing Covid-19 transmission is the delivery of sterile booths to the Kunti Village, Bungkal District, Ponorogo. It is hoped that the sterile booth will be able to break the chain of transmission of the Covid-19 virus.
\end{abstract}

Keywords: Sterile booths, Covid-19, prevention

In early 2020 the whole world was shocked by the presence of a new type of virus and the disease is called Coronavirus disease 2019 (COVID-19). This virus originates from Wuhan, China. It was discovered at the end of December 2019. According to WHO (World Helath Organization) data, we can be sure that there are 65 countries affected by this new virus. WHO named this new virus as Serve acute respiratory syndrome coronavirus-2 (SARS-CoV-2). In the beginning the transmission of this virus has not been determined to be transmitted between humans to humans. But in the end it was confirmed that its spread could spread from human to human (Relman in Yuliana, 2020). 
The new corona virus or Covid-19 is declared a pandemic by WHO and has political implications. One of them is how officials in China ask back where the virus came from. WHO itself has confirmed that China was the first to report the existence of this virus in early January 2020 after a case appeared in Wuhan, Hubei Province. The United States and China accuse each other of the origin of this pandemic. President Donald Trump called this virus the 'Chinese Virus'. But China's foreign ministry, Zhao Lijian said that it could be the United States soldiers who brought the virus to Wuhan. However, based on research published in scientific journals, Nature Medicine disputes the notion of China and the United States, as well as rejecting the theory of conspiration that this virus is a man-made or biological weapon that was intentionally created. According to research there was no evidence that the virus was created in a laboratory (Zahrotunnimah, 2020).

This virus outbreak is transmitted through droplets that come out when coughing. In addition to spreading through droplets, this virus can also stick to the surface of objects such as door handles, toilet seats, light switches, windows and others so that the spread is very fast (Van Doremalen et al, 2020). It is not only a national problem in a country, but it is already a global problem. Covid-19 hit many countries including Indonesia. In Indonesia alone the death rate due to Covid-19 is highest in Asia after China. The percentage of deaths reached 9.11\% (Syarida \& Relang Hartati, 2020). On June 24, 2020, the positive confirmed Covid-19 case reached 49,009 with 2,573 fatalities and 19,658 cases recovered (Centers for Disease Control and Prevention (CDC) data).

Many parties are competing to find a vaccine for handling this virus, but have never been found. Various efforts to prevent transmission of the virus also continue to be made. Such is the case with Universitas Negeri Malang which held Covid Edition of Real Work Lectures $(\mathrm{KKN})$ to help overcome public unrest in the midst of a pandemic. Students of Universitas Negeri Malang also helped the Covid-19 response to the community. One of the work programs of Covid UM's KKN UM is to make sterile chambers in an effort to prevent transmission of the virus.

\section{METHOD}

The method used in this activity is a survey, making, submission, and assistance. The survey was conducted on 1-3 June 2020 to find out the needs of the people of Kunti Village during the pandemic. Next, the team made a sterile cubicle on 4 - 5 June 2020. 
After the cubicle was finished, it was then handed over to Kunti Village on 6 June 2020. Students of the Community Service Study Program also assisted the use of sterile booths and participated in guarding the Covid-19 standby post.

\section{RESULTS AND DISCUSSION}

The survey conducted by the Kunti Village KKN team obtained results that the Kunti Village community needed a tool that could help prevent the transmission of the Covid-19 virus. The solution given is to make a sterile room which will be used to sterilize everyone who will enter Kunti Village.

Next, the Kunti Village Community Service Team made sterile booths made of aluminum and plastic curtains. A sterile room measuring $1 \mathrm{~m} 2$ with a height of 2 meters. The framework is made of aluminum surrounded by transparent plastic curtains as a lid. The sterile chamber frame is made of aluminum because the material is lightweight and sturdy. The disinfectant liquid will be sprayed through a small hose connected to the spraying machine. The sterile booth is designed to be effective and practical so that

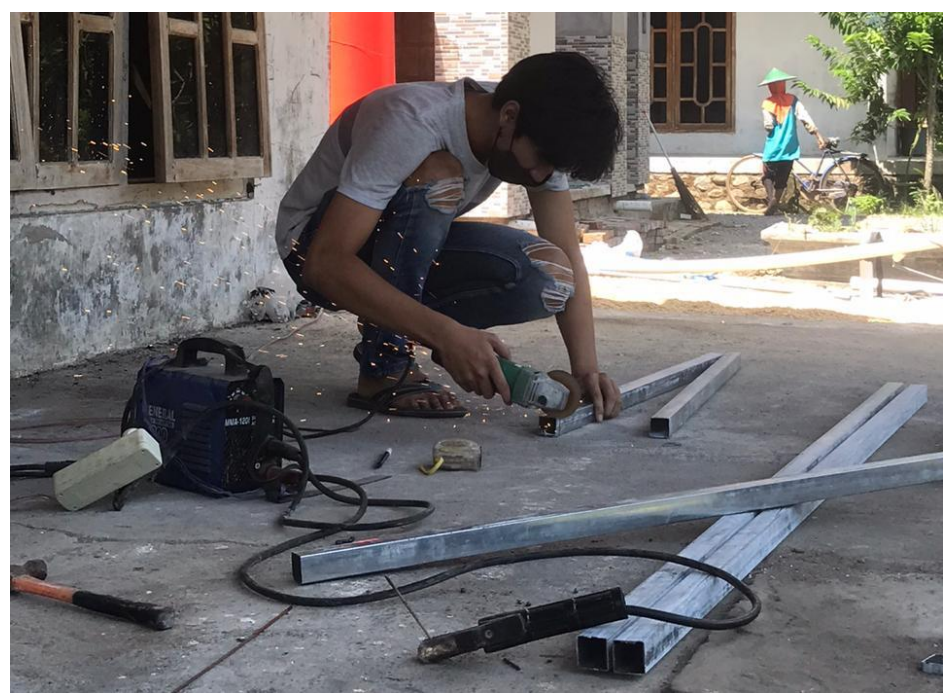

everyone can use it easily.

Figure 1. The process of making sterile chambers

Source: author's personal document 
The sterile room was handed over to the Kunti Village, Bungkal District, Ponorogo Regency by the Kunti Village Community Service students. Sterile booths which are

symbolically accepted by the Kunti Village apparatus.

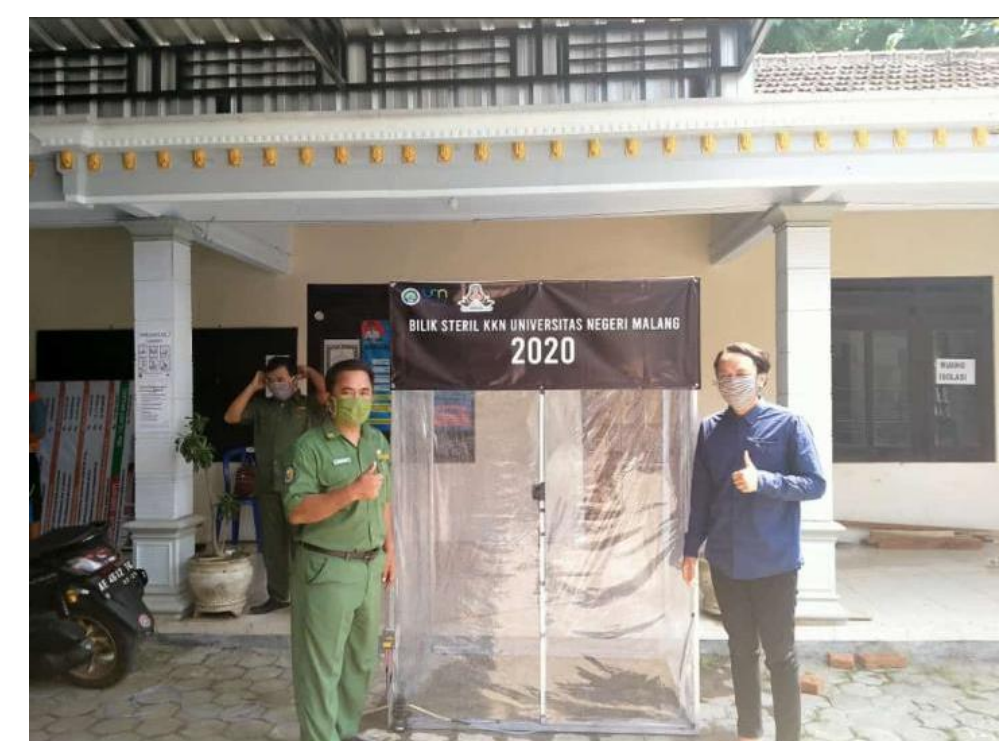

\section{Figure 2. Submission of sterile cubicles}

Source: Author's personal document

Next, sterile booths are placed in the village of Kunti. Everyone who comes to the village hall will enter a sterile cubicle. Then the sterile chamber will spray disinfectant liquid so that the virus attached to the body or clothing will die. With the stril room is expected to break the chain of transmission of the virus.

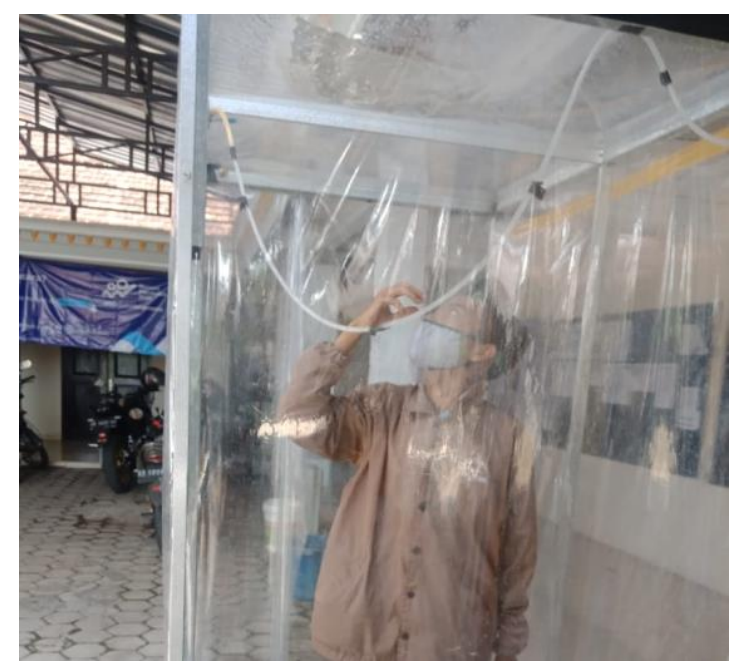

Figure 3. Use of sterile booths

Source: Author's personal document 
The sterile chamber functions as a sterilizer to prevent the spread of the Covid-19 virus. The sterile chamber will spray disinfectant liquid to the person who enters it. The disinfectant liquid will remove viruses that stick to the body or clothing.

It is hoped that the delivery of sterile booths will help the community, especially Kunti Village, in efforts to prevent the transmission of the Covid-19 virus. It is also an effort of community service carried out by students of Community Service University of Malang in Kunti Village.

\section{CONCLUSION}

KKN Universitas Negeri Malang made sterile booths in Kunti Village, Bungkal District, Ponorogo Regency. Making sterile chambers aims to prevent the spread of the Covid-19 virus in Kunti Village. Sterile booths are placed in the village hall so that every guest who visits Kunti Village can sterilize himself. Thus, the utilization of sterile chambers is expected to be able to break the chain of virus spreading and reduce the unrest of the people of Kunti Village during this pandemic.

\section{ACKNOWLEDGMENT}

Thank you to the Head of Kunti Village for helping with the Covid UM 19th edition of Community Service Program. We would also like to thank all the residents of Kunti Village who have actively participated in the prevention of the Covid-19 virus.

\section{REFERENCES}

Syafrida \& Hartati, R. (2020). Together Against Covid Virus 19 in Indonesia. Regards; Journal of Social \& Culture Syar-i, 7 (6), 495-508

Van Doremalen, N., Bushmaker, T., Morris, DH, Holbrook, MG, Gamble, A., Williamson, BN, Tamin, A., Harcourt, JL, Thornburg, NJ, Gerber, SI, Lloyd-Smith, JO , De Wit, E., \& Munster, VJ (2020). Aerosol and surface stability of SARS-CoV2 as compared with SARS-CoV-1. New England Journal of Medicine. The New England Journal of Medicine, 382 (16), 1564-1567.

Yuliana (2020). Corona Virus Diseases (Covid-19); A Literature Review. Wellness and Healthy Magazine, 2 (1), 187-192

Zahrotunnimah. (2020). Tactical Steps of Local Government in Preventing the Spread of Corona Covid-19 Virus in Indonesia. Regards; Syar-i Journal of Social \& Culture, 7 (3). 247-26 